\title{
OBRAS DE CONTENÇÃO COM ESTACAS SECANTES
}

\section{Thales Lima Affonso ${ }^{1}$ Júlio Cesar da Silva²}

Resumo: O crescente número de obras com pavimentos de subsolo, dentre a qual necessita a contenção dos terrenos para escavação, está em desenvolvimento no Brasil, porém já é amplamente utilizado na Europa e nos Estados Unidos. As Estacas Secantes têm como objetivo substituir as obras de Paredes Diafragmas escavadas com lama bentonítica. Consiste em um processo mais limpo, executando as perfurações a seco e com apenas um equipamento, podendo aproveitar o máximo dos terrenos periféricos. O resultado final é uma parede que não permite a percolação de água do lençol freático, sendo compostas por estacas que se intersectam, umas nas outras, constituindo assim um tipo de contenção, muito efetivo para solos em presença de água.

Palavras-chave: Estacas Secantes; Parede Diafragma; Meio Ambiente.

\footnotetext{
${ }^{1}$ Engenharia Civil/Universidade do Grande Rio (UNIGRANRIO), Brasil. E-mail: thales_saqua@hotmail.com.

2 Engenharia Civil/Universidade do Grande Rio (UNIGRANRIO), Brasil. E-mail: jcesarop@gmail.com.
} 